\title{
Beach Certification Schemes in Latin America: Are They Applicable to the Brazilian Context?
}

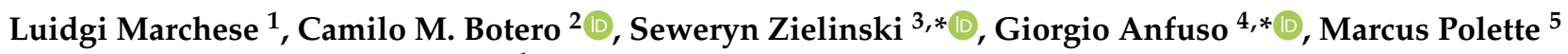 \\ and Iran Carlos Stalliviere Correa ${ }^{1}$ \\ 1 Department of Coastal and Oceanic Studies, University Federal do Rio Grande do Sul, \\ Porto Alegre 91501-970, Brazil; luidgi@gmail.com (L.M.); iran.correa@ufrgs.br (I.C.S.C.) \\ 2 Coastal Systems Research Group, Playas Corporation, Santa Marta 050022, Colombia; playascol@gmail.com \\ 3 Department of Hospitality and Tourism Management, Sejong University, Seoul 05006, Korea \\ 4 Faculty of Marine and Environmental Sciences, University of Cádiz, 11071 Cádiz, Spain \\ 5 Laboratory of Conservation and Coastal Management, University of Vale do Itajaí, Itajaí 88302-202, Brazil; \\ mpolette@univali.br \\ * Correspondence: zielinski@sejong.ac.kr (S.Z.); giorgio.anfuso@uca.es (G.A.)
}

check for

updates

Citation: Marchese, L.; Botero, C.M.; Zielinski, S.; Anfuso, G.; Polette, M.; Correa, I.C.S. Beach Certification

Schemes in Latin America: Are They Applicable to the Brazilian Context? Sustainability 2021, 13, 934

https://doi.org/10.3390/su13020934

Received: 2 December 2020

Accepted: 12 January 2021

Published: 18 January 2021

Publisher's Note: MDPI stays neutral with regard to jurisdictional claims in published maps and institutional affiliations.

Copyright: (c) 2021 by the authors. Licensee MDPI, Basel, Switzerland. This article is an open access article distributed under the terms and conditions of the Creative Commons Attribution (CC BY) license (https:// creativecommons.org/licenses/by/ $4.0 /)$.

\begin{abstract}
Beaches are multidimensional ecosystems that develop relevant natural functions and host tourist activities of great economic value. Therefore, they are currently being subjected to severe human pressure and natural impacts often enhanced by climate change. Beach certification schemes (BCSs) were designed to bridge the gap between recreation and conservation uses. The aim of this paper is to assess the compatibility and potential contribution of nine Beach Classification Schemes (BCSs) used in Latin America with the Orla Project implemented in Brazil to optimize land use planning of coastal zones, including beaches. The weaknesses and strengths of each BCSs were assessed according to the criteria for integrated coastal zone management. As a result, four of the nine BCSs were found to be the most compatible with the context of Brazilian beaches (Ecuadorian, Colombian, Cuban, and Argentinean BCSs), indicating that BCSs can contribute to specific aspects of beach management, but they should not be the only management strategy. In conclusion, the strengths of the four BCSs identified in this study can be used to build a new management tool for Brazilian beaches aligned with the Orla Project-the main coastal planning and management instrument currently used.
\end{abstract}

Keywords: beach certification; coastal management; beach management; Orla Project; Blue Flag

\section{Introduction}

Interest in tourism around the world has increased rapidly in recent years. international tourist arrivals have increased from 25 million in 1950 to 1.5 billion in 2019 and are estimated to reach 1.8 billion by 2030 [1]. In 2019, tourism generated 10.3\% of global GDP, supporting 330 million jobs. In Brazil, tourism marked recorded 6.62 and 6.35 million of international visitors in 2018 and 2019 respectively, generating 5.9 and 6.0 billion of USD and coastal and marine tourism is the largest segment of this industry [1].

According to Corbin [2], the recreational use of coastlines is a relatively recent phenomenon, since people started losing their ancestral fear and terror of beaches in the 17th century and it is only since the 20th century that beaches are considered places of rest and relaxation [3]. The use of beaches for leisure based on strong financial interests is the reason why they are considered highly productive spaces [4]. The importance of beaches for tourism is reinforced by their growing global exploitation and subsequent recognition by the World Tourism Organization [5]. Coastal tourism market is continually growing worldwide, mainly due to the attractions of sun, sea, and sand (' $3 S^{\prime}$ ' tourism), the main reason for choosing to visit coastal areas, especially beaches [6], because of coastal scenic beauty and recreational activities [7-9]. Despite the significant increase of interest in beach 
recreation in recent decades, the beach market has recorded little attention in the economic literature [10]. According to Ariza et al. [11], beaches are not only places for recreation, they constitute socio-ecological systems with three main functions: (i) natural, which refers to their characteristic as ecosystems with permanent flows of matter, energy, and information; (ii) recreational, based on people's perception of beaches as a place of leisure where they can spend their free time; and (iii) protective, which refers to the dispersion of wave energy in the lower slope of the beach and the malleability of its sediment. As a result, beaches are natural systems currently subjected to significant human pressure and uses that are often conflicting. Among human activities, tourism, urban settlements, industry, and the exploitation of natural resources are the ones responsible for accelerating the use, occupation, and degradation of beaches and coastal zones, which are often not addressed and, since the beach is part of the coast, both areas must be viewed systematically as a whole [12]. Consequently, since early 1990s, the Integrated Coastal Zone Management (ICZM) has been proposed as the preferred approach to balance development and environmental protection in coastal areas [9]. The need to apply ICZM on Brazilian beaches have only started to gain some attention in recent years [13]. Nowadays, as stated by Botero et al. [14], specialists agree that problems are complex and cannot be addressed using the traditional reductionist approach and methods (analysis-synthesis).

Beach certification schemes (BCSs) are considered a strategy for sustainable beach management since they intend to bridge the gap between recreation and conservation [15]. This strategy assesses the characteristics of a given beach using measurable compliance criteria. The schemes can be applied in the form of awards and process-based or performance-based management systems [14]. Similar to other eco-labels, BCSs grant permission to use the name and logo to certify compliance with specific requirements and indicate the recreational beach observes specific standards. In general, eco-labels can reduce the negative environmental and social impacts of tourism and ensure the tourism industry is held accountable to stakeholders [16]. It is important to note that besides a few exceptions, most BCSs are designed to recognize actions towards environmental management of usually intensively used and urbanized beaches rather than recognize those that are in pristine natural condition (e.g., [17]). Certifications can also be used as valuable marketing tools for communicating information and influencing consumer choice. In this respect, Blue Flag recognition was found to have a positive impact on the economic development of the tourism sector $[18,19]$, despite a limited public recognition shown in a number of studies $[5,15,20,21]$. Blue Flag was also found to attract higher spenders [21]. However, as beaches are public, the main direct benefits of BCSs—such as quality, safety, security, and environmental managementmight be as valuable to local authorities as the economic benefits generated from the greater number of visitors [22]. Moreover, the marketing value of BCSs is of secondary importance to the creation of strict quality evaluation schemes that constitute effective strategies for achieving environmentally sound management and visitor satisfaction [7]. In this context, even if visitors do not recognize the brand of the ecolabel $[5,15,20,21]$, they recognize the safety, good condition of infrastructure, higher cleaning regime, accessibility and other aspects demanded by BCSs [20]. In other words, beach certifications can be effective when used as templates to achieve the desired management goals [22].

Furthermore, certifications gather stakeholders around the common goal of defining standards to increase the contribution of tourism to sustainable development [23]. These standards serve as catalysts for agreements among managers, funders, and beneficiaries. Encouraging stakeholders to follow pre-established procedures, reach agreements, and make collective commitments is highly beneficial, especially in the culturally and politically complex and chaotic contexts of Latin America [14]. From the standpoint of community, BCSs can be used to pressure governmental agencies into taking specific action of general interest. Once a certification has been implemented, the local authorities are mostly responsible for its maintenance. Thus, BCSs can be used as leverage in the competition for resources [20]. Specifically, within the Brazilian context, the contributions and benefits of 
current management tools (BCSs) are still unclear [24], although some schemes (e.g., Blue Flag) were implemented nationally almost a decade ago [25].

One of the main coastal management tools in Brazil is the Orla Project, created by the Ministry of Environment (MMA) and the Secretariat of the Federal Heritage (SPU) to optimize planning and management of government-owned coastal zones based on environmental, urban, and heritage policies. The Orla Project provides direct and indirect measures for beach management in the municipalities where the project is in force. Although the mentioned project has a nationwide scope, adherence is not obligatory and application is based on the involvement and integration of stakeholders who want to adapt their actions to local requirements. Oliveira and Nicolodi [26] analyzed the results of 10 years of Orla Project and concluded that, despite a few specific problems in implementation, its goals have successfully raised awareness among the involved population and the project had a validated methodology and wide scale of application. Today, however, little is known about the most important and necessary management measures and actions in Brazilian beaches within the Orla Project [25]. Hence, the main objective of this study was to analyze the applicability of nine beach certification schemes used in Latin America (Table 1) as viable tools for beach management in Brazil within the context of the Orla Project.

Table 1. BCSs and respective countries of Latin America [14]

\begin{tabular}{ccc}
\hline $\begin{array}{c}\text { Beach Certification } \\
\text { Scheme/Abbreviation }\end{array}$ & Country & Created/Latest Version \\
\hline Blue Flag/BF & Brazil, Colombia, Puerto Rico, Dominican Republic, Mexico & $2004 / 2018$ \\
\hline INEN 2631:2012/INEM & Ecuador & 2012 \\
\hline IRAM 42100/IRAM & Argentina & 2005 \\
\hline NMX-AA-120-SCFI-2006/NMX & Mexico & 2006 \\
\hline NTS-TS-001-2/NTS & Colombia & $2007 / 2011$ \\
\hline Premio Ecoplayas/PE & Peru & $2006 / 2008$ \\
\hline Playa Natural/PN & Uruguay & $2003 / 2008$ \\
\hline Playa Ambiental/PA & Cuba & 2008 \\
\hline Bandera Azul Ecológica/BAE & Costa Rica, Panama & $1996 / 2011$ \\
\hline
\end{tabular}

\section{Conceptual Framework for Beach Management}

To better understand and compare the parameters required for the nine BCSs used in Latin America, they were been grouped into five categories: (1) environmental, (2) services; (3) safety; (4) information and education; and (5) planning and management (Table 2).

\subsection{Environmental Category}

This first category is the most recurrent in the vast majority of Latin American BCSs and includes BCSs devoted to evaluate the environmental quality of beaches. Initially, environmental does not refer to the natural and unspoiled conditions of beaches since the BCSs are based on tourist beaches [27]. Therefore, environmental quality is defined in relation to the negative effect of human action on the natural environment, especially the one linked to tourist pressure. Most references on environmental quality in tourist beaches, however, assess these factors separately without considering interactions among them or with the external environment [28]. Some authors, such as Arellano and Espejel [29], Botero [30], Cendrero and Fisher [31], and Williams [32] define environmental criteria in a more complementary manner, bearing in mind that systemic processes occur on beaches. Most common aspects generally included in the environmental category concern the assessment of bathing water quality and the abundance and characteristics of beach litter and the determination of landscape characteristics. 
Table 2. Classification criteria of the identified IMP actions

\begin{tabular}{ccc}
\hline Action Approach & Action Parameters & Categories \\
\hline 1. Water quality & \\
2. Safety & \\
3. Beach litter & \\
4. Accessibility & \\
5. Conservation & 1. Environment \\
6. Erosion & 2. Management \\
1. Directly on the beach & 7. Environmental education & 3. Services \\
2. Indirectly on the beach & 8. Information & 4. Safety \\
& 9. Infrastructure & 5. Information and education \\
& 10. Beach zoning & \\
11. Beach capacity & \\
12. Landscape & \\
& 13. Leisure activities & \\
& 14. Fixed structures/licenses & \\
\hline
\end{tabular}

\subsection{Services Compliance Category}

Within the framework of a beach management plan, the desired quality conditions and user satisfaction is achieved only when services provided at the beach are continuously improved [7]. Service requirements are described by authors such as Williams and Micallef [7], and Yepes and Cardona [29], who state that these types of requirements can strongly influence tourist destination selection. Furthermore, according to some authors (e.g., [15,33-35]), beach services like beach clean-up and beach facilities tend to decrease the naturalness of beach despite enhancing some specific aspects that benefit beach quality. This divergence, rooted in a conservationist view of management, is the result of the increased environmental impacts of tourism when these services are provided to users. In general, service compliance refers to infrastructure (bathing area limits or accessibility) and economic activities on the beaches (street vendors and beach stalls), public services (sand cleaning) or private enterprises (restaurants and hotels) to meet the needs of customers, in this case, tourists [27].

\subsection{Safety Compliance Category}

Safety compliance ensures the physical and moral integrity of users by setting guidelines for personal protection and surveillance, and managing risk from rip currents or dangerous bathing zones close to coastal defense structures [36]. Despite falling into the information category, user awareness on safety measures is also a relevant safety factor [33,36]. The most common beach safety compliance factors are the presence of lifeguards, first-aid equipment, and signs identifying high-risk locations and activities.

\subsection{Information and Education Compliance Category}

This category refers to two factors of BCSs occurring simultaneously, namely the mechanisms for provision of public information and education activities, usually environmental. The former focus on public disclosure of relevant information about the beach to promote user awareness of certain issues, such as the environmental quality of the beach, prohibited activities, and limits of the bathing zone, among others [37]. Education refers to plans and activities on the beach needed to teach users the appropriate environmental and socio-cultural conduct. These requirements essentially increase awareness of beach users and facilitate the continuous improvement process. The most common factors of this category are environmental education plans and training for the team providing services at the beach. A significant amount of research has been conducted on this topic, especially on the perception of beach users [38,39]. 


\subsection{Planning and Management Category}

This category includes factors that promote, facilitate, or require better beach organization, strategic management, and compliance with relevant regulations, usually through participatory and/or integrated management [37]. According to Kay and Alder [40], this category also includes targeting and control mechanisms of beach activities of the intervening actors. An important point of this category is the creation and maintenance of some type of local beach management body to plan, coordinate or administer the beach and optimize human, material, and financial resources $[5,37]$. The same authors stated that the most common integrated coastal management tools, such as zoning and carrying capacity, are rarely obligatory in the BCSs.

\section{Methods}

Despite the different structures, administration frameworks, and assessment procedures of the BCSs applied in Latin America, they all follow the common trend of establishing minimum compliance requirements to obtain certification and recognition. Therefore, a detailed list of more than 102 compliance requirements was prepared for all the analyzed BCSs. After establishing the compliance categories (environmental, services, security, information and education, and planning and management), the structure of each BCS was analyzed and the proportions of each requirement category was identified for each BCS according to the minimum compliance requirements.

On the other hand, sixty-three Brazilian municipalities that joined the Orla Project with an Integrated Management Plan (IMP) were analyzed. An analysis instrument was created to classify the direct actions on the beaches proposed in each IMP. These actions were classified according to their direct or indirect approach. Direct actions were considered those exclusively applied to the geographical beach area, while indirect actions were those related to both a beach and another coastal area. These management actions were classified according to the specific parameters they relate to (action parameter), and subsequently categorized (Table 2).

After calculating the proportionality of each action parameter and their representativeness in each category, a correlation matrix was used to identify the BCS compliance requirements-also present in the Orla Project. The matrix identified the possible level of compliance of each BCS in relation to the beach actions proposed by the mentioned project. In a following step, a parallel analysis was conducted in which the proportional weight of the representativeness of each category was attributed to verify possible variations regarding affinity of BCSs with actions of the Orla Project.

Subsequently, the requisites in each of the nine certification schemes used in Latin America were compared by reviewing the official guideline documents of each BCS to identify each requirement and place it in one of the aforementioned categories. The statistical differences between each category were explained by calculating the measures of central tendency for univariate descriptive analysis; although the most representative measure is the median since the data are ordinal, the third quartile was calculated as a measure of location [41]. In statistical terms, the data series included in the compliance matrix are classified as grouped ordinal data that measure only one event [41].

\section{Results and Discussion}

\subsection{Assessment of BCS in Latin America}

Concerning the BCSs analyzed, according to Botero and Zielinski [42], only the Blue Flag program covers five of the analyzed countries (Brazil, Colombia, Puerto Rico, Mexico, and Dominican Republic), while the Ecological BAE program covers two countries (Costa Rica and Panama) and the remaining BCSs are only applied in one country, as shown in Figure 1. 


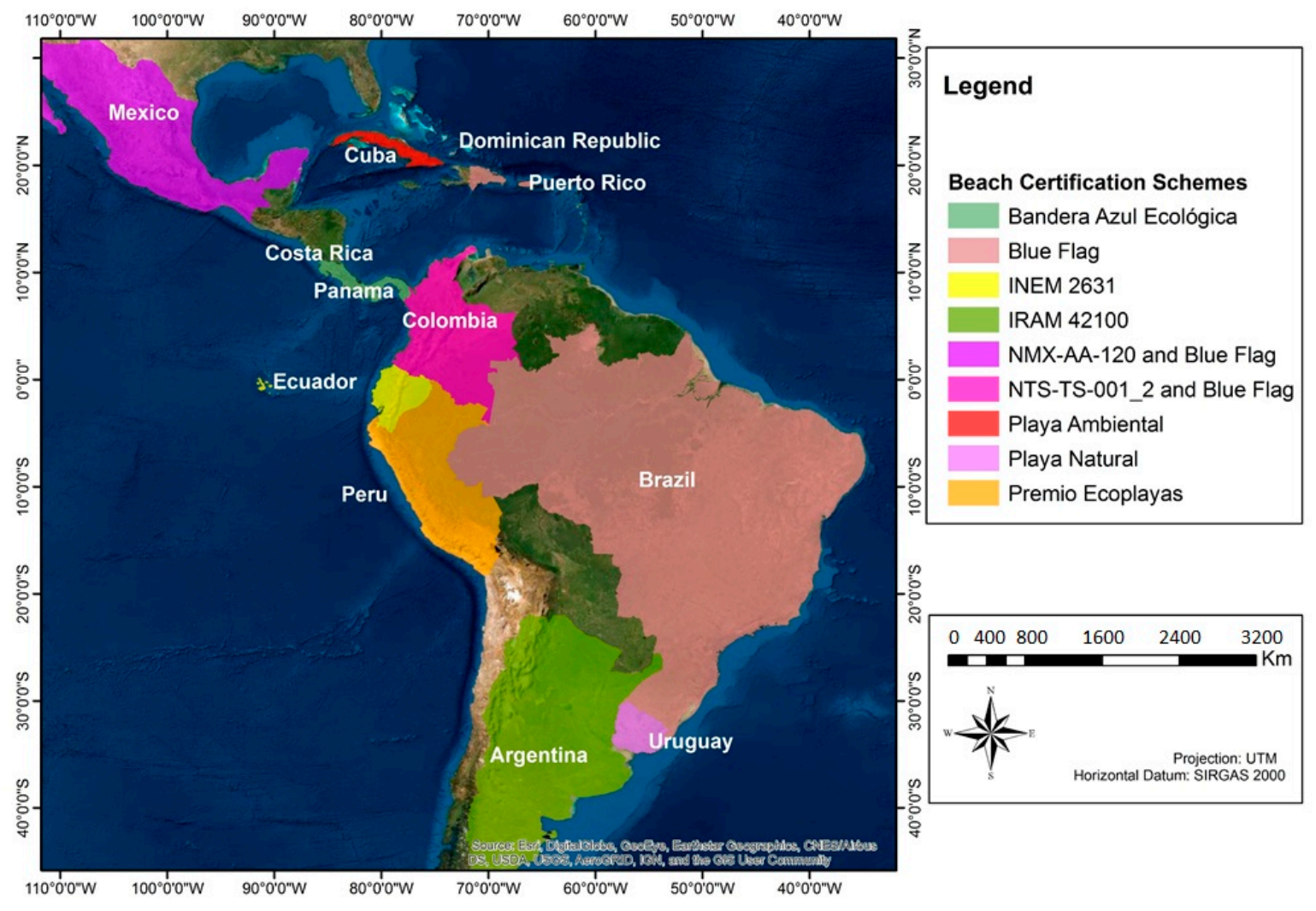

Figure 1. Geographical coverage of the nine beach certification schemes in Latin America [14].

The framework of each BCS was analyzed according to their geographical coverage and factor categories. The proportions of the factors in each BCS were identified and the number and proportion of each factor were compared for the nine BCSs. As shown in Figure 2, each BCS has a different number of conformity factors, ranging from 17 for the BAE program, to 55 for the NTS standard. This difference in the number of total factors, however, does not mean one scheme is better than other. They can be analyzed in two ways: (i) the lower the number of factors, the easier it is to understand the BCS and apply it to a given beach; (ii) the higher the number of factors, the more complete is the BCS since it covers a greater number of fundamental beach management factors, but it is more costly and difficult to implement [43], especially given the financial, technical and political barriers to certification schemes faced by developing countries [44]. Regardless, it should be noted that almost half the BCSs exceed the average number of conformity factors (37). Although four BCSs are under the average, they are close to that value, indicated with a black line in Figure 2.

The category analysis, however, is more interesting than the total number. The tendency of each category is more clearly shown in the line graph of Figure 2. A deeper analysis reveals that the environmental category has the highest number of factors in most of the BCSs, demonstrating a significant interest of these schemes in environmental management, especially in the Colombian (NTS), Argentinean (IRAM), and Ecuadorian (INEM) schemes. The categories services and safety have an important number of factors in almost all the BCSs, although they are highlighted in the PAM certification and the Eco-Praias Award in relation to services and the NTS and the PAM certification in relation to safety. The category information and education is clearly the least specified factor in most of the BCSs. It is mostly addressed in the Colombian NTS, Ecuadorian INEM, and Uruguayan Playa Natural schemes. The category planning and management, which Botero and da Silva [37] considers crucial, is mostly considered in the NTS scheme. 


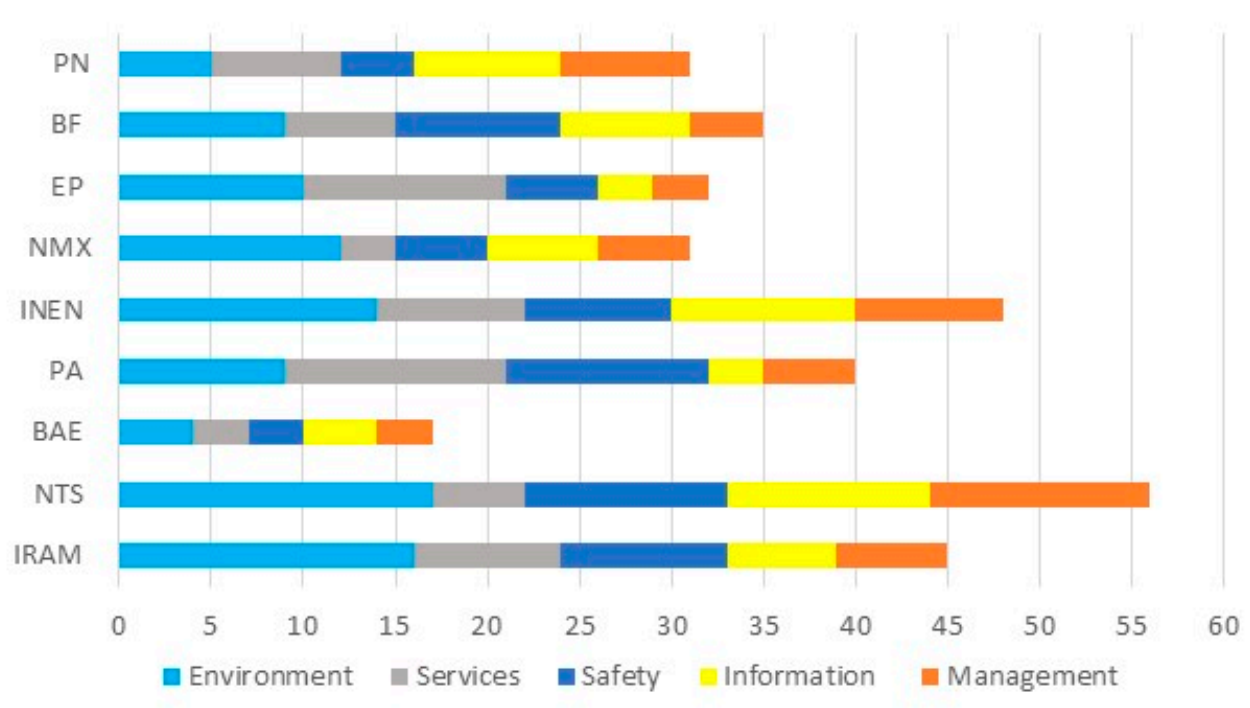

Figure 2. Proportion of conformity factors by planning and management category in the nine Latin American BCSs [14]. For abbreviations see Table 1.

In summary, a significant, albeit unexaggerated variability was observed in the number of conformity factors; with the exception of the ecological Blue Flag program, all the other BCSs have between 31 and 55 conformity factors in total. Similarly, most of the BCSs are decompensated regarding the proportion of category factors, although the Ecuadorian and Costa Rican schemes are more balanced despite a variation in the environmental factor (in the first case). The balance of categories based on the measurement of the BCSs, however, is practically perfect, with a slight variation only in the environmental factors.

An additional descriptive analysis is related to the proportion of conformities of each certification, in each category, according to total requirements. As observed in the inner circle of Figure 3, two categories have a higher total number of factors (environment and management), while the other three have the highest average (services, safety, and information). This result shows the similarity between the BCSs and reveals as the total proportion of factors is broadly moderated in terms of average.

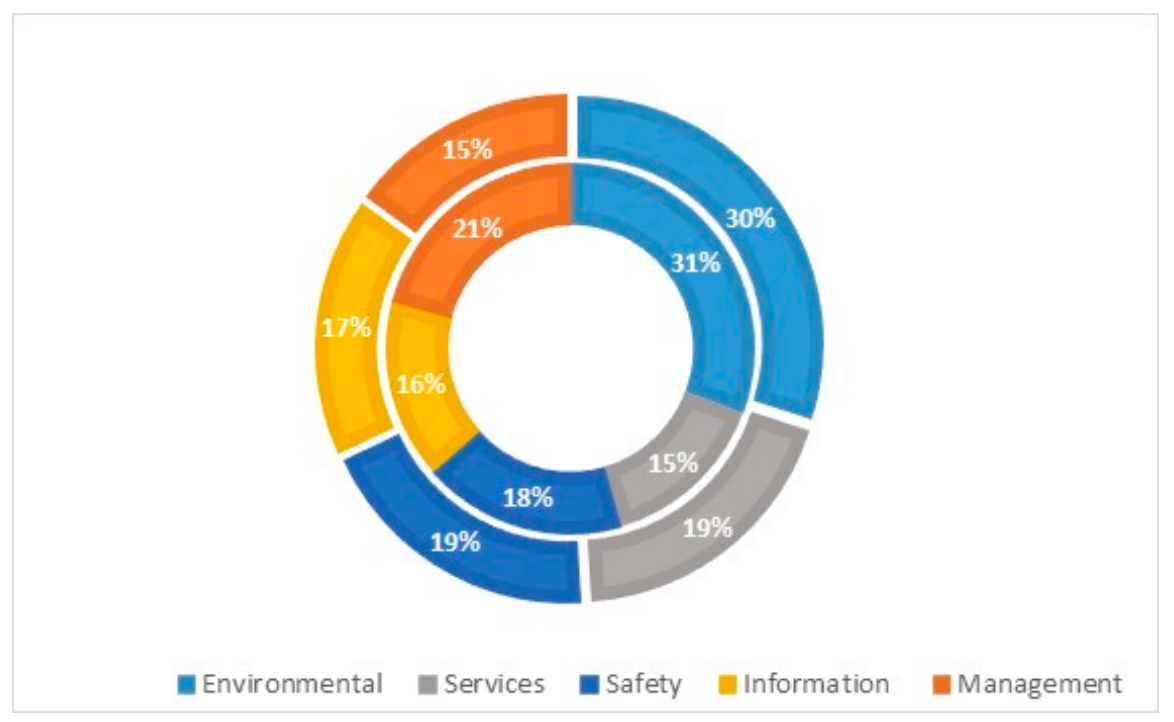

Figure 3. Proportion of factors by category in relation to conformity factors (inner circle = proportion of total factors; outer circle $=$ proportion of averages). 
The central tendency measures were calculated to explain the statistical differences between each category by means of univariate descriptive analyses (Figure 4). Although these are ordinal data, the most representative measure is the median. Therefore, the third quartile was also calculated as a measure of location [41]. For the central tendency, the two categories safety and management had similar behavior in all three measures. For services and information and education, however, the average is practically the same as the median. This particularity indicates the category is less affected by extreme values, whether high or low, and the categories are more consistent in terms of proportion of conformity factors.

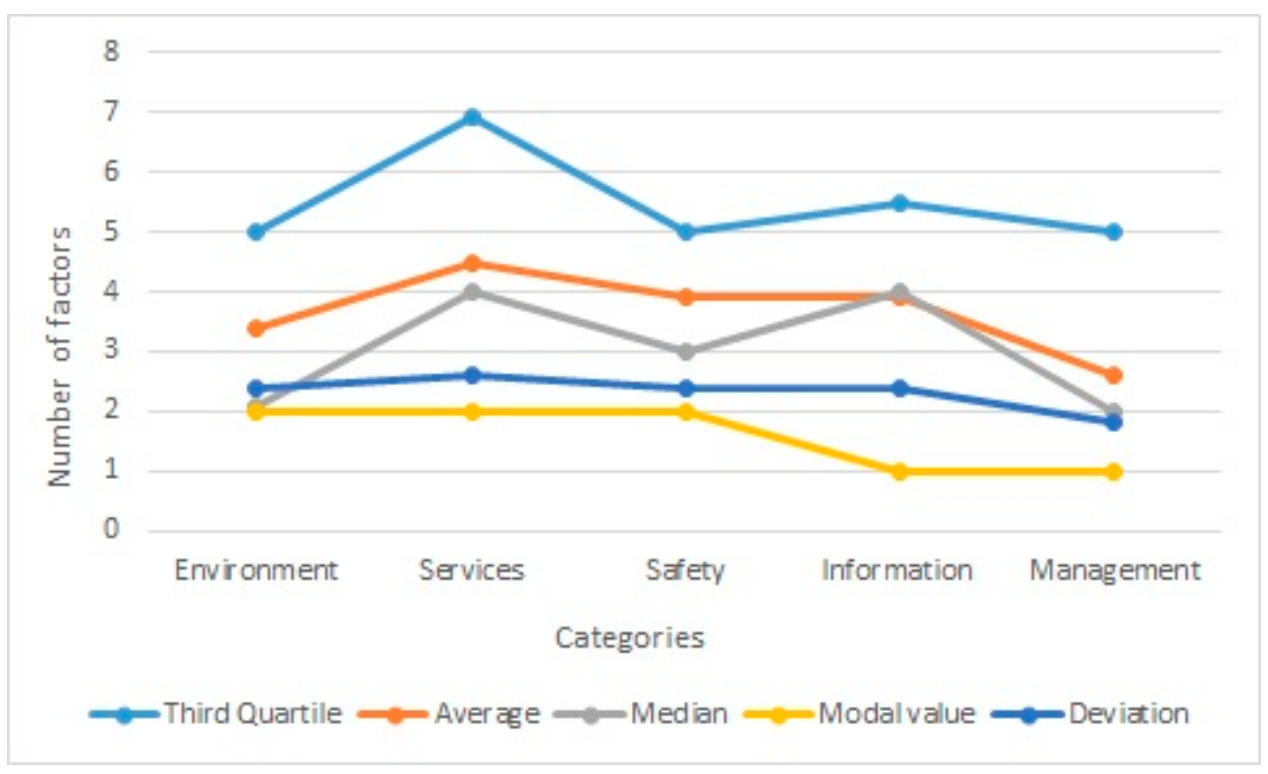

Figure 4. Measures of central tendency of the compliance category factors [14].

In contrast, the data deviation is quite high due to the variability of each BCS and the inclusion of very specific requirements for each national scenario. According to Williams and Micallef [7], one of the central aspects of beach management is clarity of the evaluated requirements since a very high variable only confuses beach managers. The case of nine Latin American BCSs perfectly applies to this statement. Similarly, Botero [30] complements this finding by suggesting the use of minimum requirements for all the BCSs, such as the type of beach being evaluated, the presence of a beach management committee, the existence of monitoring platforms, beach records, management programs, critical conformity factors, level-based beach use certification, and audits of effectiveness considering integrated coastal management criteria.

\subsection{BCSs' Requirements and Brazilian Beach Management}

Brazil has $8698 \mathrm{~km}$ of coastline, of which $7635 \mathrm{~km}$ is relatively straight coastline and $1300 \mathrm{~km}$ is made up of bays and gulfs. The Brazilian coastline is divided into 395 municipalities and in four regions (south, southeast, northeast, and north) according to the common characteristics of each region [45]. This study focuses on 63 of the municipalities that joined the Orla Project voluntarily and designed and disclosed their integrated management plans. Figure 5 shows the analyzed municipalities with IMP by region. The northeast region is the most represented, followed by the southeast and south regions, while the north region has the least significant number of municipalities with IMPs. 


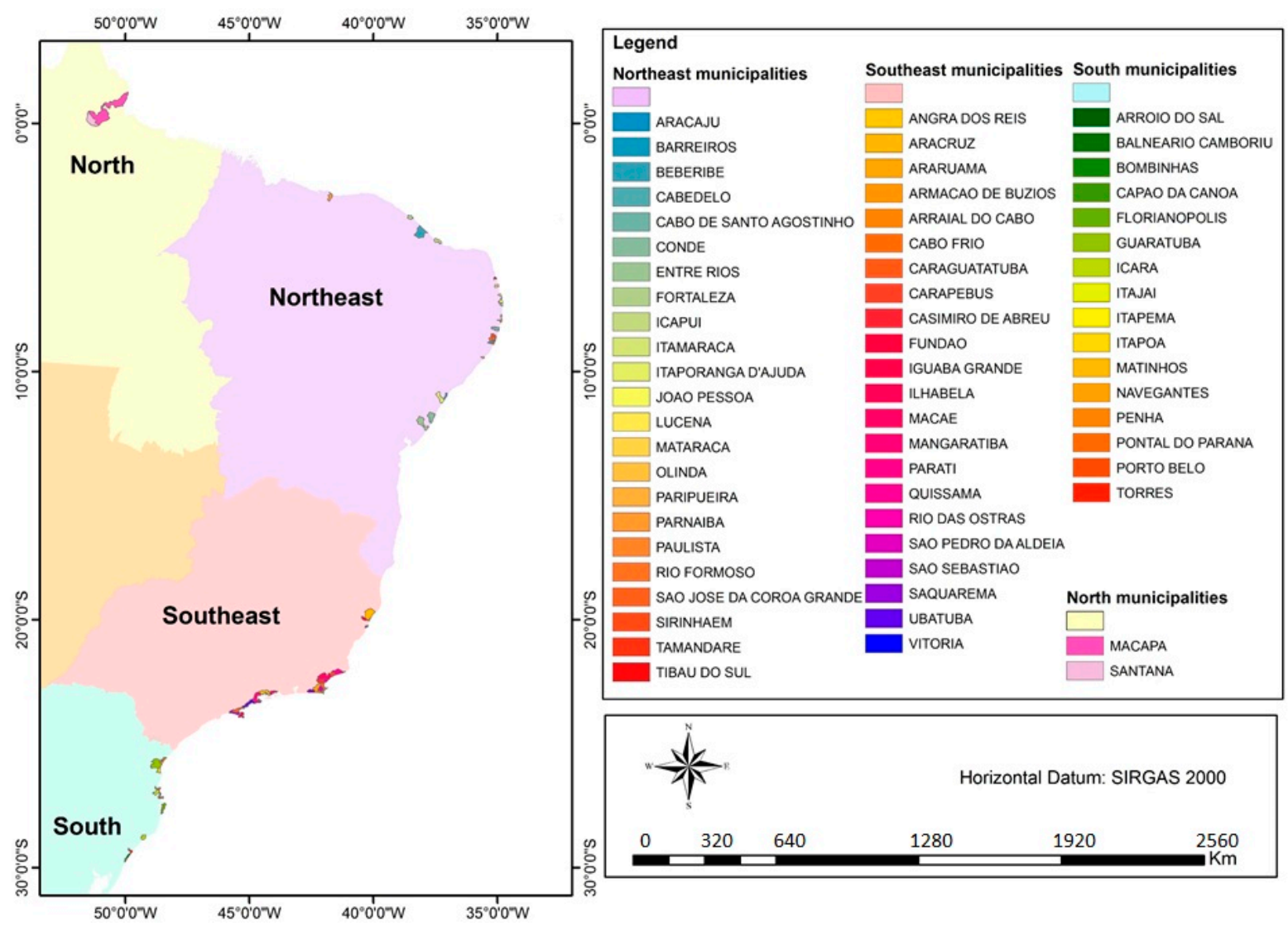

Figure 5. Brazilian municipalities with integrated management plans.

Considering the entire country, the category of 'environmental factors' was the most widely represented (37\%) (Figure 6). This category involves parameters such as ecosystem conservation (e.g., dunes and seagrasses maintenance), monitoring of bathing water quality, solid waste disposal, coastal erosion monitoring, noise control, and illegal fishing surveillance. This category is followed by the category 'land use management' (23\%) and 'services' (21\%). The category 'planning and management' primarily refers to licenses and permission for the occupation and use of beaches and surrounding areas, as well as the zoning of activities and uses of the beach. In the case of planning and management, the licenses of use and occupation of the Brazilian coast are a major obstacle of the Orla Project, mostly because the occupation of these areas does not follow the legal limits established by the Orla Project [46,47]. Article 23 of Decree 5300 (D.O.U., 2004) states that the occupation limit of urbanized areas is 50 meters or 200 meters for non-urbanized areas toward the continent from the high tide line or final limit of the ecosystem. Most Brazilian coastal municipalities, however, have failed to achieve these limit goals [48], thus justifying the high representativeness of actions and measures related to this aspect and the $23 \%$ of factors in the planning and management category.

Another representative factor in the planning and management category was beach zoning. Most management plans identified this issue because the areas for specific activities are not mapped or signaled in most of the beaches in the Brazilian municipalities. The range of recreational, sports, economic, or contemplative activities that people can practice on beaches warrants the need to organize these areas according to their respective uses to avoid conflicts and for safety reasons [37]. None of the actions considered the density of users on the beach and its carrying capacity. According to Silva et al. [49], these criteria are considered key variables for integrated beach management. However, the actions on Brazilian beaches related to these parameters based on IMP analysis are still non-existent. 


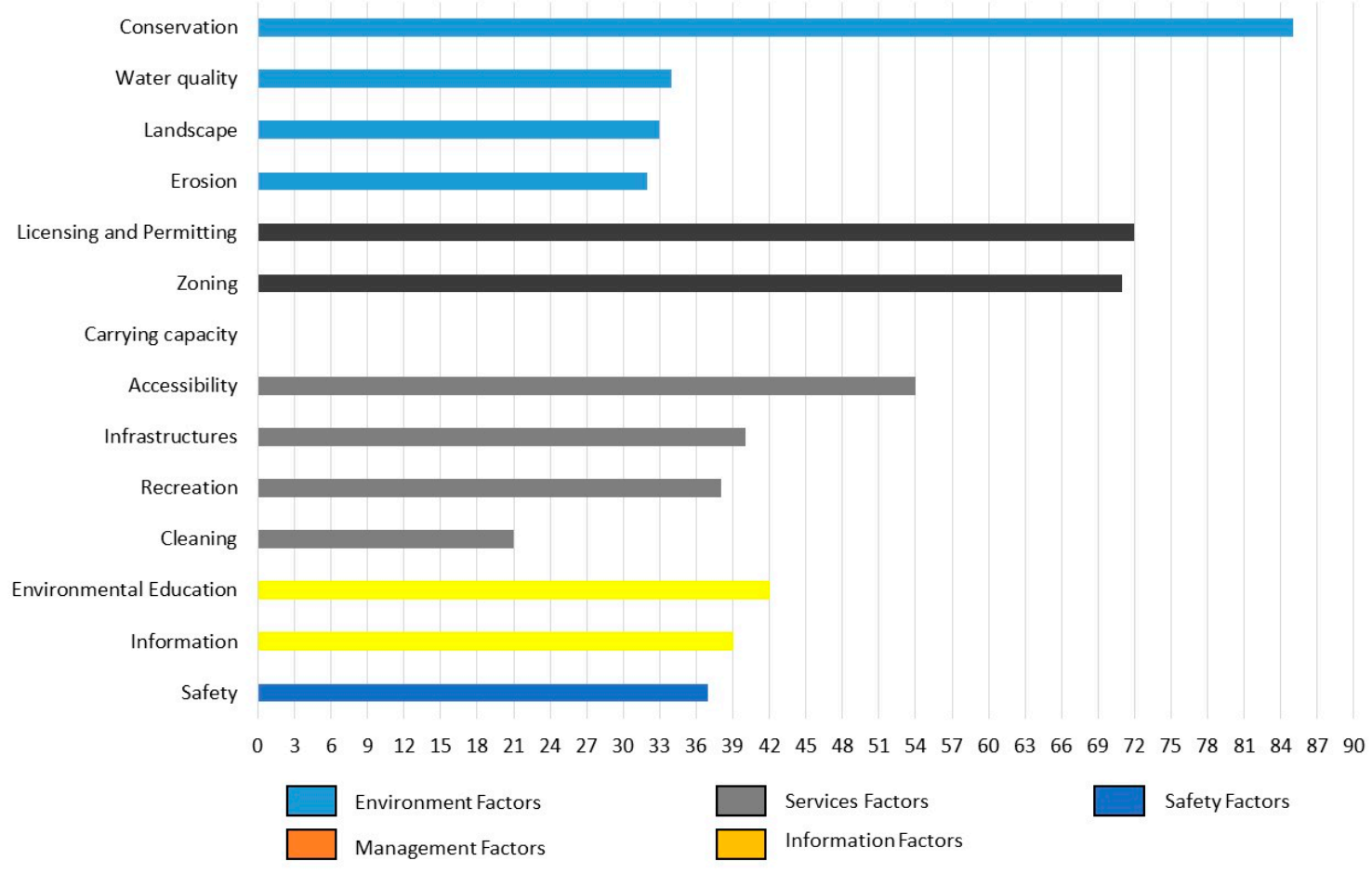

Figure 6. Direct beach criteria based on actions of the Orla Project.

The category of service factors (21\%) primarily consists of measures to address conflicts of accessibility to beaches, general infrastructure, and recreation. According to Brazilian Law 7661/88 (D.O.U, 1988), beaches are defined as "public common use areas with guaranteed and permanent free access to the beaches and sea in any direction, with the exception of areas of the national interest or security or included in protected areas by specific legislation". Consequently, the urbanization or any form of land use in the coastal zone that may prevent or hinder access to the beach should not be permitted. The reality, however, does not fully correspond to the law since access to some beaches is the main cause of conflict in the coastline $[47,50]$. The other two factor categories, 'information and education' $(13 \%)$ and 'safety' ( $6 \%)$, had the lowest number of measures and actions of the analyzed IMPs. However, these factors are also considered important. Pranzini et al. [36], for example, define a broad framework to improve beach safety management, including signing, lifeguard services, and risk assessment. Previously, Brewster [45] addresses several aspects of lifesaving activities on beaches.

When the IMPs of the Brazilian municipalities were analyzed, however, the results are similar to those found by Scherer [25], in which the most relevant problems of the Brazilian coast are the result of chaotic land occupation and predatory exploitation of natural resources. The direct consequences of the socio-environmental issues include water contamination due to lack of sanitation, diminished diversity of natural landscapes, coastal erosion, loss of public assets, reduced access to public locations (beach), biodiversity loss, and suppression of the Atlantic forest and resting vegetation.

Figure 7 compares the real conflicts in Brazilian municipalities by correlating the IMP action in the beaches and the BCSs compliance requirements. In general, the BCS with the best assessment and the greatest number of compliance requirements in line with the Orla Project was the Ecuadorian scheme (INEN). The following four BCSs with the highest assessment scores were the Cuban BCS PAM, the Colombian BCS (NTS), and the Argentinean BCS (IRAM), respectively. 


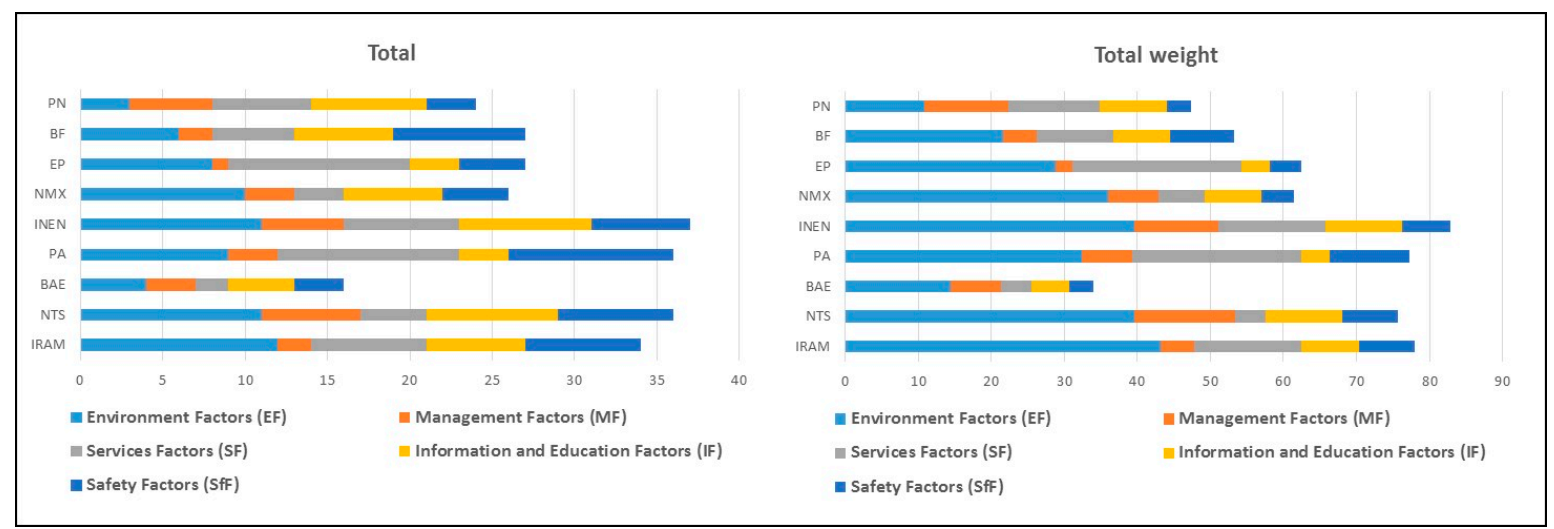

Figure 7. Total assessment of conformity factors by category, both 'no weight attributed' (left) and 'weight attributed' (right).

In terms of weight of the conformity factor categories of the same BCSs according to the overall representativeness of Orla Project actions (environment $=3.6$; management $=2.3$; services $=2.1$; information $=1.3$; safety $=1.1$, the Ecuadorian INEN also, regardless of the attribution of weight per category (Figure 8). The other three BCSs maintained the high rating with the Argentinean IRAM ranking second, followed by the Cuban PAM in third, and the Colombian NTS in fourth position.

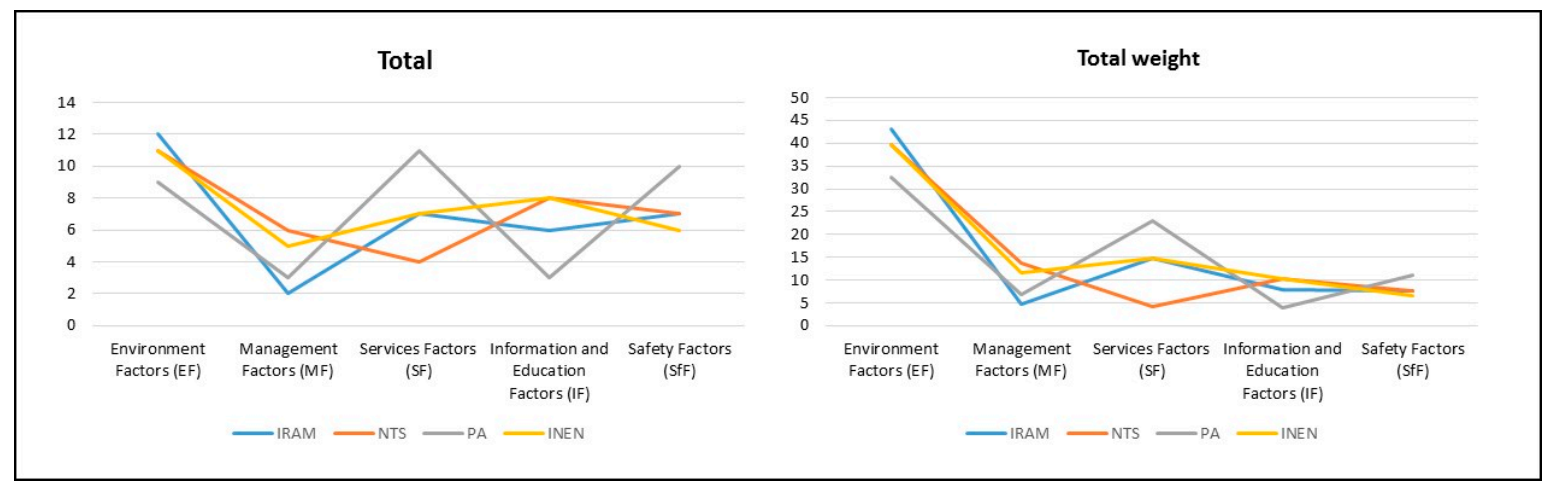

Figure 8. Classification by category of the four best evaluated BCSs.

The four BCSs mentioned above ranked higher than the others with little difference between the points attributed to them in the assessments. Therefore, the compliance criteria of these BCSs are compatible with the current management needs of Brazilian beaches identified in their respective management plans. Consequently, these BCS can serve as reference for the investigation of appropriate beach management tools, as also stated by other authors $[7,14,43,51]$. This analysis also reveals that the most relevant contributions of the BCSs for the Orla Project predominantly lie in the conformity factor categories related to the environment and services, followed by safety and information and education, and, finally, planning and management (Figure 8).

The 'environment' category had the highest number of factors that comply with the recommended beach requirements. This result reveals two things. Firstly, priority measures on Brazilian beaches are related to environmental conflicts. Hence, the BCSs with the highest scores in this category can be used as viable management tools. In this respect, various BCSs and Orla Project share a biocentric vision of coastal management and emphasize the conservation of ecosystems.

While this is a positive outlook, a strategy for integrated coastal management should also integrate other categories such as planning and management, where relevant economic and social factors are included. When these aspects are considered secondary, the coastal 
management initiatives are more likely to fail because they do not correspond to the reality of the municipalities and their capacity for management [14].

This explains the low rate of employment of Orla Project actions and the low number of certified beaches in Brazil.

Although the 'planning and management' category is critical, it was found to be the least representative regarding the compatibility between the BCSs and the Orla Project, suggesting gaps in beach management even in the best BCSs.

The remaining factor categories can potentially guide the management of Brazilian beaches. Thus, the four highest scoring BCSs can contribute to the establishment of beach management protocols in Brazil. However, significant gaps involving social and environmental factors that are critical for effective management were also detected. According to Peña-Alonso et al. [52], highly vulnerable beaches are those that have been transformed by anthropogenic actions. Therefore, it is necessary to improve the integration of social and economic data into beach management practices considering they are unique ecosystems and increasingly exposed to human-induced pressures [53,54].

\subsection{Strengths and Weaknesses of BCSs for ICZM in Brazil}

Each one of the four BCSs with the highest potential contribution to the Orla Project was individually subjected to a strengths and weaknesses analysis using a recurrence matrix. To identify ICZM actions and fundamental management requirements for beach management in Brazil, 32 criteria were analyzed and arranged into five categories (Table 3).

Table 3. Classification criteria categories, strengths and weaknesses matrix

\begin{tabular}{|c|c|c|c|c|}
\hline Environment & Management & Services & Safety & Information \\
\hline 1. Erosion & 13. Zoning & 22. Recreation Services & 26. Policing & 29. Services provided \\
\hline 2. Odors & 14. Carrying capacity & $\begin{array}{l}\text { 23. Friendly } \\
\text { architecture }\end{array}$ & 27. Water rescue & 30. Beach plan \\
\hline $\begin{array}{l}\text { 3. Ecosystem } \\
\text { conservation }\end{array}$ & $\begin{array}{l}\text { 15. Beach management } \\
\text { committee }\end{array}$ & 24. Access & $\begin{array}{l}\text { 28. Risk prevention } \\
\text { and control }\end{array}$ & $\begin{array}{l}\text { 31. Environmental } \\
\text { information }\end{array}$ \\
\hline $\begin{array}{c}\text { 4. Natural } \\
\text { characterization }\end{array}$ & 16. Beach typology & 25. Sanitary services & & $\begin{array}{l}\text { 32. Safety } \\
\text { recommendations }\end{array}$ \\
\hline $\begin{array}{l}\text { 5. Water and } \\
\text { sand quality }\end{array}$ & 17. Labelling & & & \\
\hline 6. Sanitary sewage & $\begin{array}{l}\text { 18. Permanent } \\
\text { monitoring }\end{array}$ & & & \\
\hline 7. Recycling & $\begin{array}{l}\text { 19. Financial support } \\
\text { strategies }\end{array}$ & & & \\
\hline 8. Noise & $\begin{array}{l}\text { 20. Environmental } \\
\text { sustainability policy }\end{array}$ & & & \\
\hline $\begin{array}{l}\text { 9. Protection of } \\
\text { native species }\end{array}$ & 21. Legal requirements & & & \\
\hline \multicolumn{5}{|l|}{$\begin{array}{l}\text { 10. Environmental } \\
\text { education }\end{array}$} \\
\hline \multicolumn{5}{|l|}{ 11. Landscape } \\
\hline 12. Solid Waste & & & & \\
\hline
\end{tabular}

A simple matrix was created to quantify the strengths and weaknesses of each analyzed BCS and highlight only the truly unique factors of each category. The results of this matrix helped identify factors that are not evident when reviewing the documentation of each BCS. From a holistic perspective, implementation of the BCSs was analyzed to identify the context of each situation. The number of strengths and weaknesses does not indicate 
whether one BCS is better than the other since only one structural strength can be more relevant than five functional weaknesses.

\subsubsection{INEM-Ecuador}

The structure of the INEM is more consistent and clear than the other BCSs. It was also the BCSs that is the most compatible with the reality of Brazilian beaches identified by the Orla Project (Figure 9). The main factors that differ in its structure are assessment of unique requirements in three types of beaches (urban, rural, and uninhabited) and certification by the level of compliance.

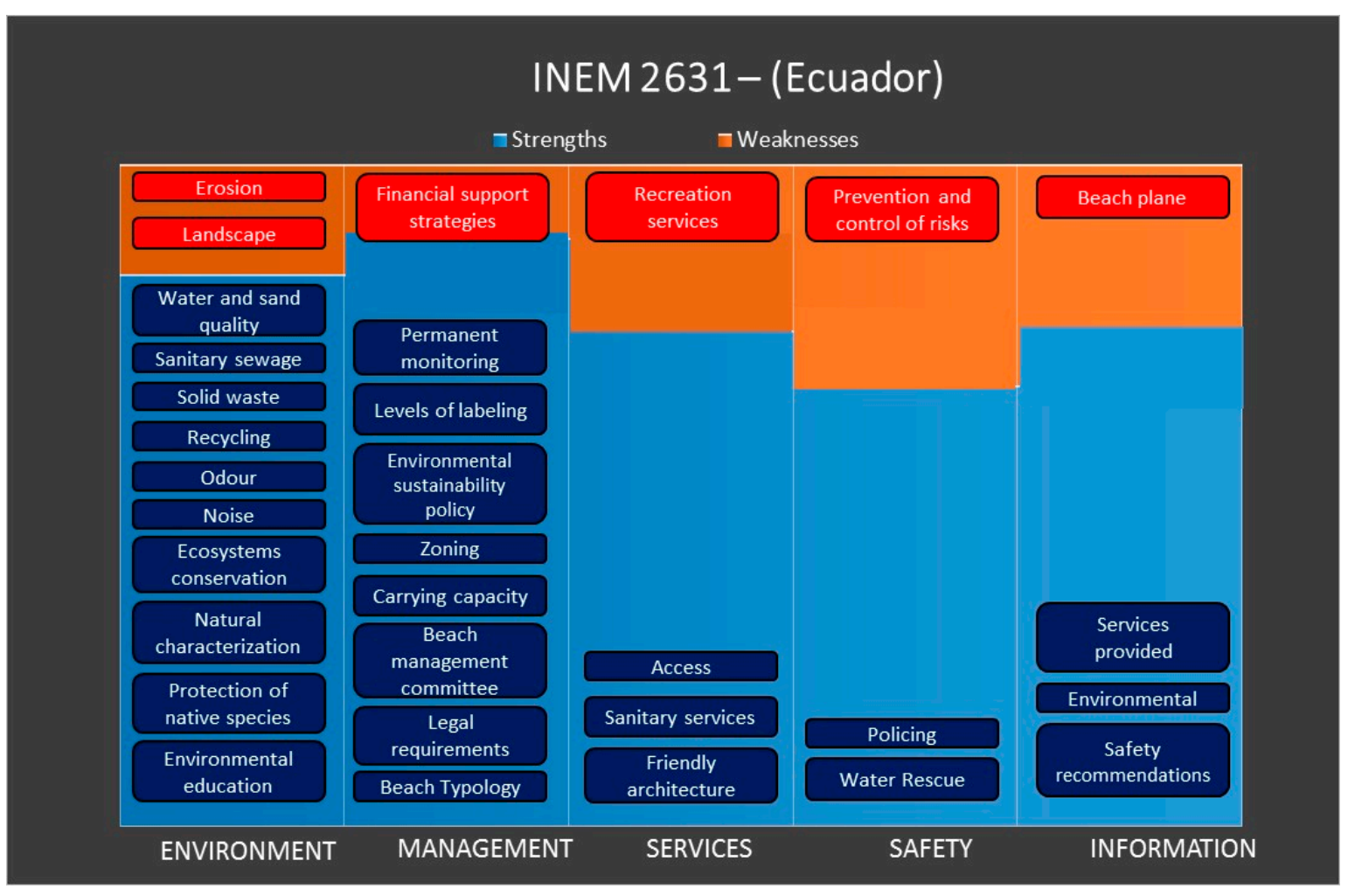

Figure 9. Strengths and weaknesses of the Ecuadorian BCS INEM.

The classification of beaches carries significant weight in certification since each type of beach has a specific compliance level for the requirements in each category. This classification of beach types fills the void of BCSs that Williams and Micallef [7] considered the most relevant. These authors recommend classifying beaches in different types since each one of them requires different management actions and levels of amenities. This should be the initial requirement for BCSs to establish prior management conditions according to the beach type. Moreover, three levels of certification graphically defined by stars should be established to maintain and motivate continuous improvements in beach management. The need to establish different certification labels and adapt to specific circumstances was considered crucial some time ago by Buckley [55] and more recently by Boevers [56], Williams and Micallef [7], and Zielinski and Botero [18] especially in terms of beach certification. Nevertheless, only three out of nine BCSs in Latin American countries define the need for amenities according to beach type and only two offer different levels of certification. However, the minimum level of compliance (class $C$ ) required by this BCS is still very strict in the Brazilian and wider Latin American context because of the complicated relationship between public and private uses of the beaches.

The strengths of the BCS are centered in compliance and the recording of data, including standardized forms for collecting information. This scheme requires permanent weekly monitoring, which generates a permanent source of information of crucial beach 
conditions. Moreover, the information allows a national agency to easily and cheaply construct a solid database of all certified beaches in the country. This practice complies with the most integrated coastal management manuals that provides sufficient information for decision making (e.g., [56,57]).

Another strength of the BCS INEN 2631 is the full set of standardized forms included with the norm, allowing each beach manager to survey information almost immediately. This particular aspect has been identified as a weakness of the other studied BCSs. Furthermore, INEN clearly defines the establishment of a beach management agency and its key actors responsible for administering and certifying beaches. According to Botero and da Silva [37], the beach management agency is a mixed administrative, non-profit body with participatory regimes and autonomy in its conformation and decisions regarding ICZM. It enables the control of system interactions and ensures their stability inclusively and independently. According to François [58], the beach management agency is a higher level of organization emerging from social systems based on a critical level of inter-relations. As defined by the WTO [59], beaches have a wide range of stakeholders and, therefore, require cooperation agreements to monitor interactions. This scheme was also considered the most comprehensive since it gathers environmental, tourist, safety, and management factors in almost equal proportions and relevance, thus indicating a focus on integrated coastal management. The weaknesses include an excessive number of requirements for the first level of certification, hindering its implementation. It also fails to include important aspects regarding erosion, landscape, and risk assessment and prevention plans.

\subsubsection{Playa Ambiental-Cuba}

The Cuban certification PAM has representative compliance requirements that are consistent with the demands of Brazilian beaches. The categories that scored the highest on the compatibility with the Orla Project were environment, services, and safety (Figure 10). The category with the worse assessment was management. The structure of this BCS does not comply with zoning factors and it does not include obligatory and permanent monitoring or establish strategies for financial support. Moreover, the compliance factors of this BCS do not consider beach type. Therefore, the BCS was fairly unrepresentative of the category planning and management. Also, it did not include an outline for forming the beach management committee or mechanisms to assess user satisfaction or perception. According to Silva [60], the perception of users is valuable and useful to management since these results serve as inputs to manage a specific beach. Authors such as Nelson and Botterill [15] and Vaz [61] consistently criticize the lack of interest in the perception of beach users and argue this is the only feedback the system receives from users.

This BCS was a provincial endeavor, so it does not consider different types of beaches. As mentioned previously, the failure to include beach type classifications in a certification is considered a significant weakness since beach type determines the course of management [7]. In spite of this weakness, the PAM certification is quite consistent and evidently created using scientific rigor. It is also heavily environment-oriented and the services and safety factors are quite consistent with the Brazilian context.

Its structure is composed of two clearly differentiated blocks. Firstly, the BCS establishes four general requirements. Once these requirements are met, the beach must comply with thirteen categories of indicators. Each category has a percentage score defined by a group of experts [62]. A negative point in the assessment, however, is that the scheme does not consider labelling even if it has some grade of compliance. The support for this BCS has always been provided by a body responsible for the coastal management of the region of application. However, this successful characteristic of the Cuban BCS was only possible because the norms are clear in this country, especially Decree-Law 212 of 2000, which rigorously regulates beach activities and establishes the bodies responsible for administering the coast. Without this regulatory clarity, it would be impossible to know which organization is in charge of the coast, as occurs in most Latin American countries. This feature is, therefore, considered a positive point of the BCS. 


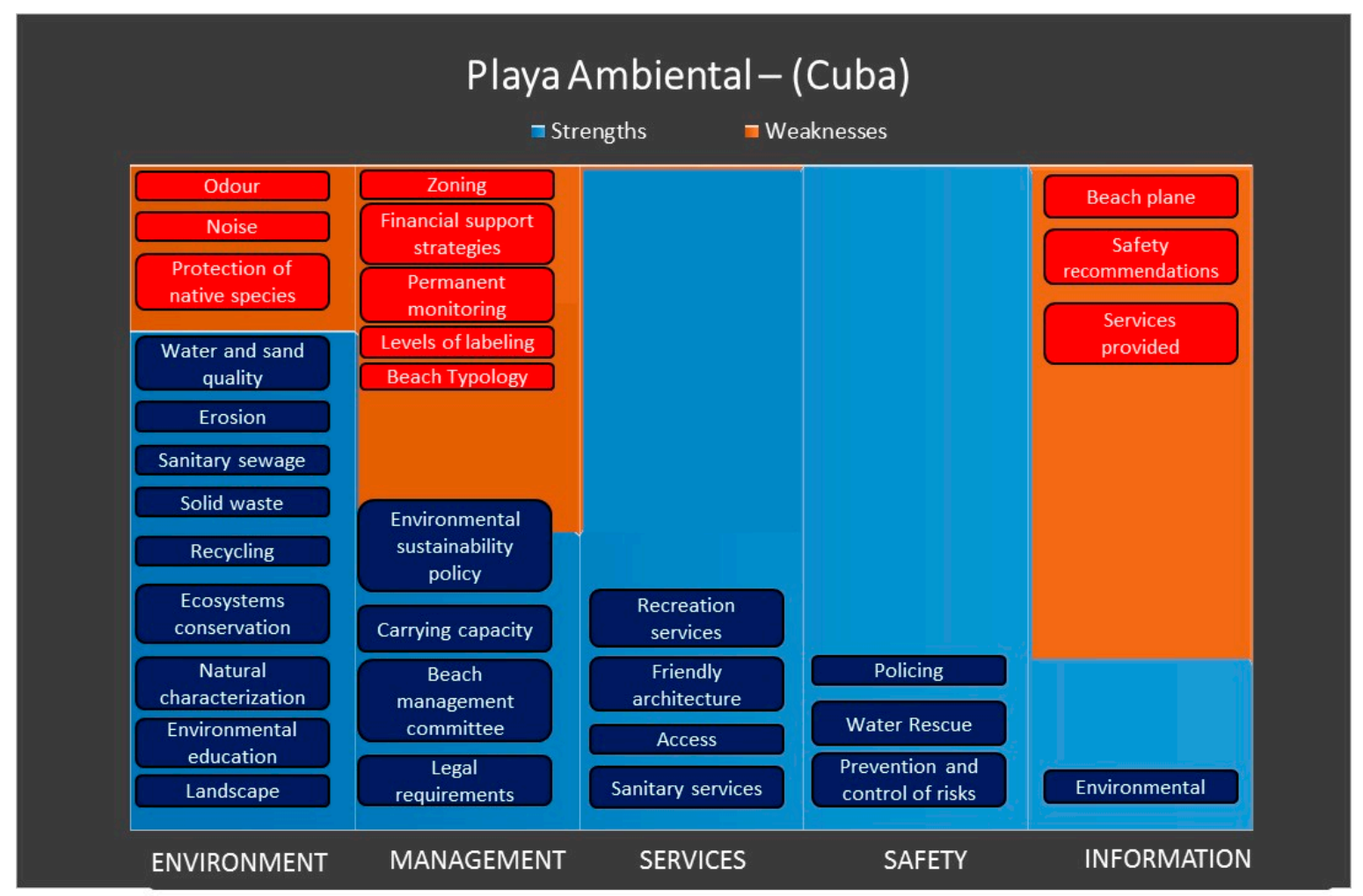

Figure 10. Strengths and weaknesses of the Cuban BCS PAM.

\subsubsection{NTS-Colombia}

The most important strength in the Colombian BCS NTS is the inclusion of sociocultural factors in management. Many of the requirements are related to beach vendors and to planning and management. The issue of beach vendors, which is not very relevant in other latitudes and therefore controversially included in the Colombian scheme, is highly significant in Brazil and Latin America because hundreds of families depend on this source of income [28]. This BCS positively integrates user satisfaction and complaints, considered fundamental for integrated beach management by many authors [14,15,61]. This factor in the certification, however, is not used as a mechanism to control compliance of beach management, but only as a source of information for the system. Another strength is the assessment of landscape factors and, above all, the assessment of beach carrying capacity, which Silva [60] considers fundamental for urban tourist beaches since it provides inputs for management and streamlines the use of financial resources of the municipalities.

Although the scope of application of the NTS standard is tourist destinations rather than a specific beach as the main attraction, one of the weaknesses of this scheme is the non-observance of beach types, as recommended in specialized scientific literature [7]. Moreover, it does not contain certification levels, forcing fulfilment of all requirements. These excessively high demands for the studied scenario hinder the achievement of goals and discourage managers from using the management tool in Latin America [18].

The lack of strategies to obtain financial support (Figure 11) was also identified. Funding is important to maintain the BSC since periodic water quality and ecosystem monitoring require professional expertise [22]. According to Bendell and Font [63], government financial support is crucial for half of the existing certification programs around the world. With regard to integrated coastal management criteria, another weakness of this BCS is the absence of requirements for the formation of a beach management committee. 


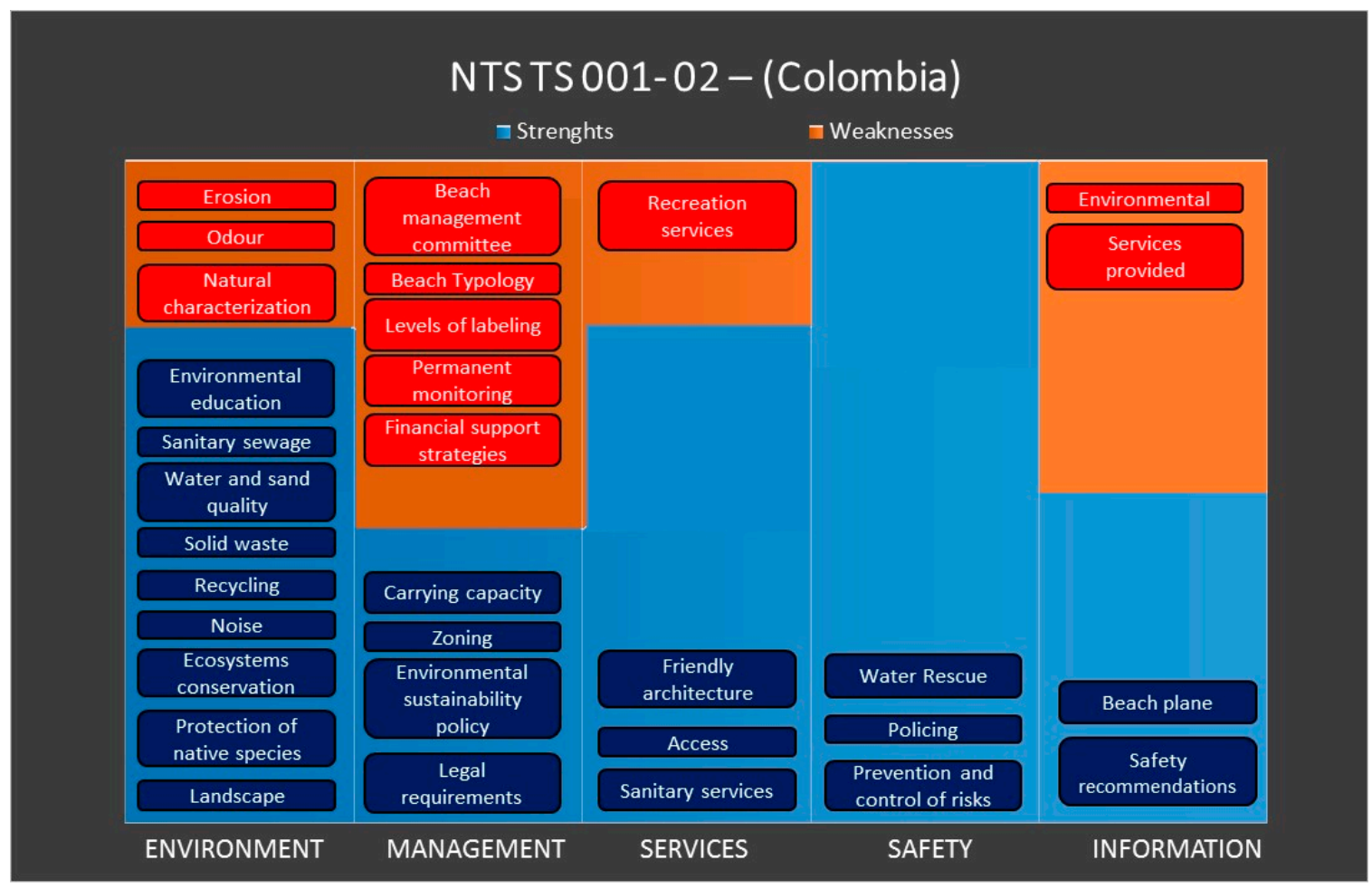

Figure 11. Strengths and weaknesses of the Colombian BCS NTS.

\subsubsection{IRAM-Argentina}

Unlike in all the other countries in Latin America, the IRAM certification is not applied to beaches or destinations, but to a private unit under a concession for use of the beach called a balneario or bathing area. According to Dadón [64], application of the standard at a micro and local scale allows for a more detailed analysis of the stakeholders and a closer inspection of the experiences of each certified bathing area. Since this BCS is given to private organizations and the application area usually does not often 100 square meters of beach, its contribution to actual integrated coastal beach management is minimal. Moreover, beach fragmentation to obtain a certification seals is more related to a marketing and advertising strategy than to efficient management, although it does allow private stakeholders to fully commit to integrated beach management [65]. In traditional '3S' destinations, which can house up to 20 balnearios side by side on the beach, certification becomes more of a distribution of 'independent coastal sectors' or 'cells'. This factor was identified as a significant weakness (Figure 12).

Another weakness of this BCS is that the requirements do not include the use of members of the local community to manage beaches or the creation of a management committee. It also does not consider local community and beach users' perceptions, which is an important source of feedback $[14,66]$.

Furthermore, the framework was not designed to consider the beach as a whole and, therefore, carries a number of representative weaknesses of the category planning and management, including the lack of zoning and carrying capacity assessment mechanisms. The high cost of implementation required to acquire the standard and the lack of compliance requirements related to permanent beach monitoring are other significant weaknesses. For this reason, the BCS IRAM received the lowest points in the fundamental category planning and management among the BCSs most suitable for the Brazilian scenario. 


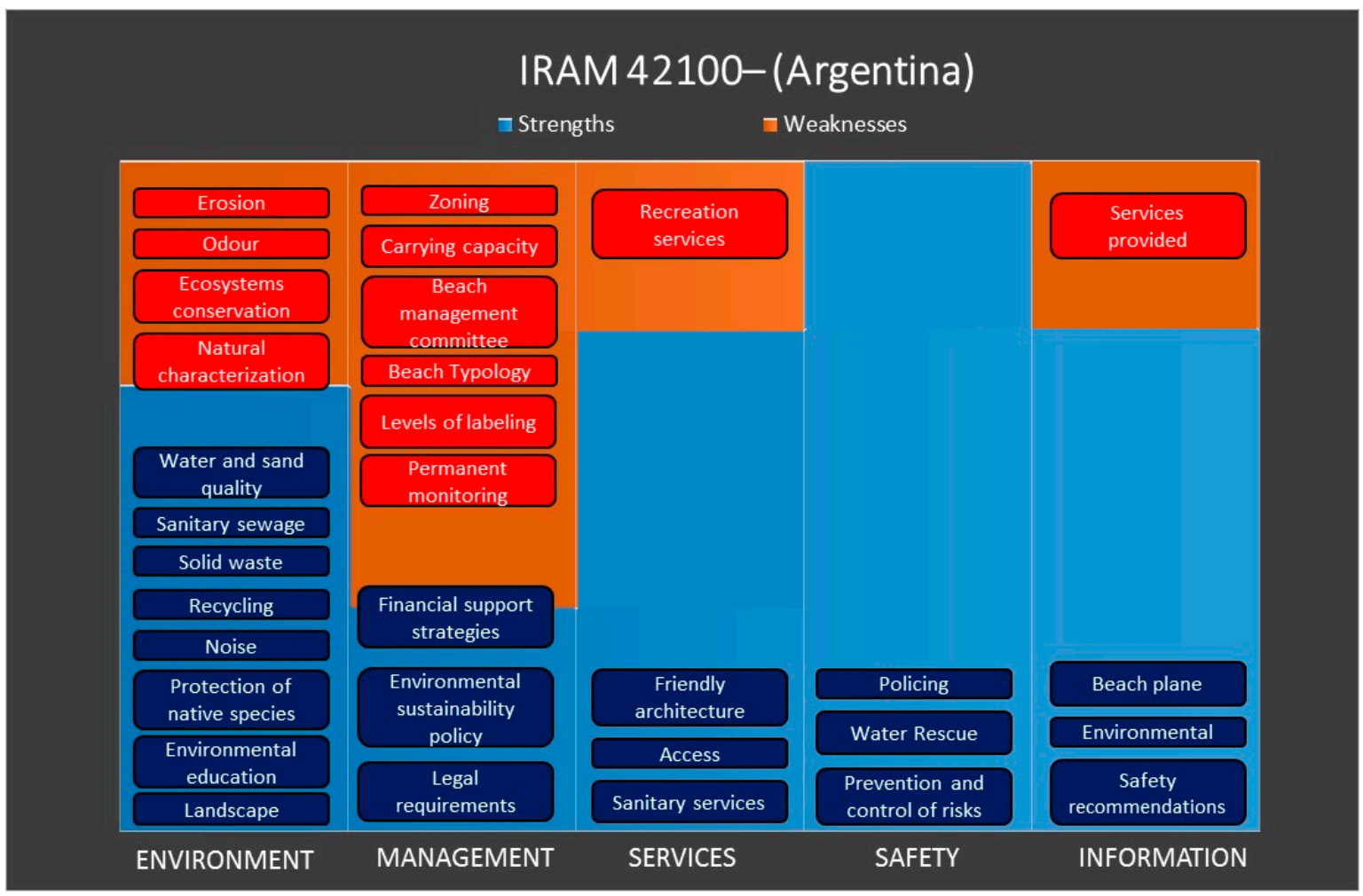

Figure 12. Strengths and weaknesses of the Argentinean BCS IRAM.

The strengths of this BCS lies in the assessment of eco-friendly landscape and architecture. The most important and exclusive strength of this BCS, however, is the inclusion of a value chain. According to Zielinski and Botero [22] and Bendell and Font [63], the relevance of this factor lies in the need to finance management, which is surprisingly absent in most of the other schemes. Interestingly, these schemes promote large investments in infrastructure, information, and services, but do not mention any financing mechanism. Thus, as noted by McKenna et al. [20], in the future, authorities may learn to appreciate cheaper certifications tailored to very specific conditions. One of the solutions would be to design a certification approach that includes fewer but more effective requirements, thus reducing the cost of implementation and ensuring the maintenance of high standards. The strengths and weakness of the four BCSs reveal that they have specific elements with the potential to significantly contribute to beach management when used with other ICMZ tools on Brazilian beaches. When used as stand-alone methods, however, their potential as ICMZ strategies is limited. Therefore, an application of any of the analyzed BCSs in its entirety is not an ideal solution. To maximize the benefits, there is a need for a new management instrument that includes the strengths of the four BCSs identified in this paper.

\section{Conclusions}

Although beach certification schemes have been widely used as a management tool in the last 15 years in Latin America, their implementation is very scarce in relation to the number of beaches used for tourism. Based on the analysis of 63 municipal coastal management plans within the Orla Project framework, ICZM initiatives such as policies, programs, and strategies revealed a gap between classical coastal management at local and national level and beach management on a smaller scale.

In addition to analyzing beach certifications as a hypothetical management tool, the paper analyzed the compatibility of BCSs from Ecuador, Cuba, Colombia, and Argentina with the Orla Project showing that beach management in the Brazilian coasts could be greatly improved if some aspects of those BCSs were integrated into the IMP. Require- 
ments such as carrying capacity, zoning, establishment of a beach management body, and others are valuable inputs designed to enhance coastal zone management from a wider perspective. Despite the continued application of ICZM instruments that were usually not adapted to the challenges faced by beaches, BCSs are a viable option to reinforce and validate integrated coastal management. Consequently, management must be reinstated from a new, broader, and more complex epistemological approach than reductionism and positivism, since these approaches limit the scope of natural and legal sciences, respectively. Brazil is a global hotspot for biological and cultural diversity with thousands of beaches that are suitable and adapted to the implementation of sustainable tourism as the main socio-economic asset. If the Orla Project is properly adjusted to effectively include beach management tools, such as BCSs, there should be no doubts as to its fundamental importance for the wellbeing of Brazilians and tourists.

Author Contributions: Conceptualization, C.M.B., M.P., I.C.S.C. and S.Z.; Methodology, L.M.; Software, L.M.; Formal analysis, L.M.; Investigation, L.M. and S.Z.; Resources, C.M.B. and M.P.; Data curation, L.M.; Writing—original draft preparation, L.M.; Writing—review and editing, G.A., C.M.B., I.C.S.C. and S.Z.; All authors have read and agreed to the published version of the manuscript.

Funding: This research received no external funding.

Acknowledgments: Luidgi Marchese would to thank the Conselho Nacional de Desenvolvimento Científico e Tecnológico (CNPq) for the financial support for this research. All authors are members of the PROPLAYAS Network. This work is a contribution to the PAI Research Group RNM-328 Andalusia, Spain.

Conflicts of Interest: The authors declare no conflict of interest.

\section{References}

1. UNWTO. World Tourism Barometer and Statistical Annex, Jan. 2020; World Tourism Organization: Madrid, Spain, 2020; Volume 18, pp. 1-6.

2. Corbin, A. El Territorio del Vacío. Occidente y la Invención de la Playa; Editorial Mondadori: Barcelona, Spain, 1993; pp. 1750-1840.

3. Rubio, D. Gestión Integral de Playas. Agencia Valenciana de Turismo; Editorial Sintesis: Madrid, Spain, 2005.

4. Houston, J.R. The economic value of beaches-A 2013 update. Shore Beach 2013, 81, 3-10.

5. Nelson, C.; Morgan, R.; Williams, A.T.; Wood, J. Beach awards and management. Ocean Coast. Manag. 2000, 43, 87-98. [CrossRef]

6. Dodds, R.; Kelman, I. How Climate Change is Considered in Sustainable Tourism Policies: A Case of The Mediterranean Islands of Malta and Mallorca. Tour. Rev. Int. 2008, 12, 57-70. [CrossRef]

7. Williams, A.; Micallef, A. Beach Management: Principles and Practice, 1st ed.; Earthscan: London, UK, 2009.

8. Mooser, A.; Anfuso, G.; Mestanza, C.; Williams, A. Management implications for the most attractive scenic sites along the andalusia coast (SW Spain). Sustainability 2018, 10, 1328. [CrossRef]

9. Mestanza-Ramón, C.; Chica-Ruiz, J.A.; Anfuso, G.; Mooser, A.; Botero, C.M.; Pranzini, E. Tourism in Continental Ecuador and the Galapagos Islands: An Integrated Coastal Zone Management (ICZM) Perspective. Water 2020, 12, 1647. [CrossRef]

10. Mendoza-González, G.; Martinez, L.M.; Guevara, R.; Pérez-Maqueo, O.; Garza-Lagler, C.M.; Howard, A. Towards a Sustainable Sun, Sea, and Sand Tourism: The Value of Ocean View and Proximity to the Coast. Sustainability 2018, 10, 1012. [CrossRef]

11. Ariza, E.; Sardá, R.; Jiménez, J.A.; Mora, J.; Ávila, C. Beyond Performance Assessment Measurements for Beach Management: Application to Spanish Mediterranean Beaches. Coast. Manag. 2007, 36, 47-66. [CrossRef]

12. Botero, C.M.; Telles, D.H.Q.; González, M.; Ariza, E. Ciencias de la Complejidad Como Base Para una Gestión Integrada de los Sistemas Costeros: Aplicación al Sistema Playa. En: Soto, D. y Palacios, M. El reto de la Agenda 2030: Desafíos Éticos y Experiencias Ambientalistas en Iberoamérica; Colección Pacífico 20/20; UPACÍFICO: Quito, Ecuador, 2020; Volume 3, pp. 187-212. ISBN 978-9942-8633-4-8.

13. Cristiano, S.; Portz, O.L.; Anfuso, A.; Rockett, G.; Barboza, E. Coastal scenic evaluation at Santa Catarina (Brazil): Implications for coastal management. Ocean Coast. Manag. 2018, 160, 146-157. [CrossRef]

14. Botero, C.; Williams, A.T.; Cabrera, J.A. Advances in Beach Management in Latin America: An Overview From Certification Schemes. Environ. Manag. Gov. Adv. Coast. Mar. Resour. Coast. Res. Libr. 2014. [CrossRef]

15. Nelson, C.; Botterill, D. Evaluating the contribution of beach quality awards to the local tourism industry in Wales the Green Coast Award. Ocean Coast. Manag. 2002, 45, 157-170. [CrossRef]

16. Font, X.; Sanabria, R.; Skinner, E. Sustainable tourism and ecotourism certification: Raising standards and benefits. J. Ecotourism 2003, 2, 213-218. [CrossRef]

17. Mir-Gual, M.; Pons, G.X.; Martín-Prieto, J.A.; Rodríguez-Perea, A. A critical view of the Blue Flag beaches in Spain using environmental variables. Ocean Coast. Manag. 2015, 105, 106-115. [CrossRef] 
18. Merino, F.; Prats, M.A. Sustainable beach management and promotion of the local tourist industry: Can blue flags be a good driver of this balance? Ocean Coast. Manag. 2020, 198, 105359. [CrossRef]

19. Capaci, S.; Scorcu, A.E.; Vici, L. Seaside tourism and eco-labels: The economic impact of Blue Flags. Tour. Manag. 2015, 47, 88-96. [CrossRef]

20. McKenna, J.; Williams, A.T.; Cooper, J.A.G. Blue Flag or Red Herring: Do beach awards encourage the public to visit beaches? Tour. Manag. 2011, 32, 576-588. [CrossRef]

21. Saayman, M.; Saayman, A. How Important Are Blue Flag Awards in Beach Choice? J. Coast. Res. 2017, 33, 1436-1447. [CrossRef]

22. Zielinski, S.; Botero, C.M. Myths, misconceptions and the true value of Blue Flag. Ocean Coast. Manag. 2019, 174, 15-24. [CrossRef]

23. Font, X. Critical Review of Certification and Accreditation in Sustainable Tourism Governance. 2005. Available online: http: / / www.crrconference.org/downloads/font.pdf (accessed on 18 January 2018).

24. Marchese, L.; Conde, D.; Polette, M. La Gobernanza en el Funcionamiento de los Servicios del Sistema de Gestión Ambiental de Playas de Montevideo (Uruguay). Revista Sustentabilidade em Debate; Universidade de Brasília (UnB): Brasília, Brasil, 2013.

25. Scherer, M. Gestão de Praias no Brasil: Subsídios para uma Reflexão (Beach Management in Brazil: Topics for Consideration). Rev. Gestão Costeira Integr. 2013, 13, 3-13. [CrossRef]

26. De Oliveira, M.R.L.; Nicolodi, J.L. A Gestão Costeira no Brasil e os dez anos do Projeto Orla. Uma Análise Sob Ótica Poder Público 2012, 12, 89-98. [CrossRef]

27. Botero, C.M.; Cabrera, J.A.; Zielinski, S. Tourist Beaches. In Encyclopedia of Coastal Science; Finkl, C., Makowski, C., Eds.; Springer: Cham, Switzerland, 2018. [CrossRef]

28. Botero, C.; Pereira, C.; Tosic, M.; Manjarrez, G. Design of an index for monitoring the environmental quality of tourist beaches from a holistic approach. Ocean Coast. Manag. 2015, 108, 65-73. [CrossRef]

29. Arellano, P.; Espejel, I. Propuesta de una metodología para evaluar playas recreativas con destino turístico. Revista de Medio Ambiente. Tur. Sustentabilidad 2009, 2, 119-130.

30. Botero, C. Utilidad de los esquemas de certificación de playas para el manejo integrado costero: Evaluación de ocho certificaciones en Iberoamérica. Rev. Cienc. PC 2009, 4, 27-41.

31. Cendrero, A.; Fisher, D. A procedure for assessing the environmental quality of coastal areas for planning and management. J. Coast. Res. 1997, 13, 732-744.

32. Williams, A.T. The flag jungle. Fort Lauderdale Mag. 2004, pp. 42-46. Available online: https://fortlauderdalemagazine.com/ (accessed on 3 December 2020).

33. Yepes, V.; Cardona, A. Mantenimiento y explotación de las playas como soporte de la actividad turística. El plan de turismo litoral 1991-99 de la comunidad Valenciana. Memorias Jornadas Españolas Ingeniería Costas Puertos Coruña 2000, II, 857-876.

34. Defeo, O.; McLachlan, A.; Schoeman, D.; Schlacher, T.; Dugan, J.; Jones, A.; Lastra, M.; Scapini, M. Threats to sandy beach ecosystems: A review. Estuar. Coast. Shelf Sci. 2009, 81, 1-12. [CrossRef]

35. Schlacher, T.; Thompson, L. Physical Impacts Caused by Off-Road Vehicles to Sandy Beaches: Spatial Quantification of Car Tracks on an Australian Barrier Island. J. Coast. Res. 2008, 24, 234-242. [CrossRef]

36. Pranzini, E.; Pezzini, G.; Anfuso, G.; Botero, C. Beach Safety Management. In Beach Management Tools. Concepts, Methodologies and Case Studies; Botero, C.M., Cervantes, O., Finkl, C.W., Eds.; Springer: Dordrecht, The Netherlands, 2017.

37. Botero, C.M.; da Silva, C.P. Beach Management Tools. In Encyclopedia of Coastal Science; Finkl, C., Makowski, C., Eds.; Encyclopedia of Earth Sciences Series; Springer: Cham, Switzerland, 2018. [CrossRef]

38. Cervantes, O.; Botero, C.M.; Finkl, C.W. State-of-the-Art Users' Perception on Beaches from the Tree of Science Platform. In Beach Management Tools-Concepts, Methodologies and Case Studies; Botero, C., Cervantes, O., Finkl, C., Eds.; Coastal Research Library; Springer: Cham, Switzerland, 2018; Volume 24. [CrossRef]

39. Lucrezi, S.; Saayman, M.; Van der Merwe, P. An assessment tool for sandy beaches: A case study for integrating beach description, human dimension, and economic factors to identify priority management issues. Ocean Coast. Manag. 2016, 121, 1-22. [CrossRef]

40. Kay, R.; Alder, J. Coastal Planning and Management, 2nd ed.; Taylor \& Francis: London, UK, 2005.

41. Hurtado, Y.P. Determinación de un Modelo de Medición de Capacidad de Carga en Playas Turísticas de Uso Intensivo, Como Herramienta Para el Manejo Integrado Costero. Aplicación en la Playa El Rodadero (Santa Marta, Colombia). Master's Thesis, Universidad del Magdalena, Santa Marta, Colombia, 2010.

42. Botero, C.M.; Zielinski, S. The implementation of a world-famous tourism ecolabel triggers political support for beach management. Tour. Manag. Perspect. 2020, 35, 100691. [CrossRef]

43. Zielinski, S.; Botero, C. Are eco-labels sustainable? Beach certification schemes in Latin America and the Caribbean. J. Sustain. Tour. 2015, 23, 1550-1572. [CrossRef]

44. Sasidharan, V.; Sirakayab, E.; Kerstetter, D. Developing countries and tourism ecolabels. Tour. Manag. 2002, 23, 161-174. [CrossRef]

45. Instituto Brasileiro de Geografia e Estatística. Brazilian Institute of Geography and Statistics. 2017. Available online: https://cidades. ibge.gov.br/brasil/panorama (accessed on 12 March 2018).

46. Pinto, A.C. Projeto Orla no Litoral do Estado de Santa Catarina. Master's Thesis, Universidade do Estado de Santa Catarina, Florianópolis, Brasil, 2014.

47. Polette, M. Desafio Para a Implementação de um Programa de Gerenciamento Costeiro em Nível Municipal Para o Litoral Brasileiro; Luidgi: Itajaí, Brazil, 2003. 
48. Polette, M.; GESAMP; ICAM; PNGC. Análise Comparativa Entre as Metodologias de Gerenciamento Costeiro Integrado; Ciência e Cultura: São Paulo, Brazil, 2003; Volume 55, Available online: http://cienciaecultura.bvs.br/pdf/cic/v55n4/a17v55n4 (accessed on 6 November 2020).

49. Silva, C.P.; Nogueira, M.R.; Moutinho, G.; Mota, V. Beach carrying capacity and protected areas: Management issues in Arrábida Natural Park, Portugal. J. Coast. Res. 2016, 75, 680-684. [CrossRef]

50. Moraes, A.C.R. Contribuição Para a Gestão Costeira do Brasil: Elementos Para Uma Geografia do Litoral Brasileiro; Annablume: São Paulo, Brasil, 2007; p. 232. ISBN 9788574196770.

51. Cagilaba, V.; Rennie, H. Literature Review of Beach Awards and Rating Systems (Report No. 2005/24); Environmental Waikato: Hamilton, Spain, 2005.

52. Peña-Alonso, C.; Jurado, P.F.; Calvento, L.H.; Chacón, E.P.; Arizá, E. Measuring geomorphological vulnerability on beaches using a set of indicators (GVI): A tool for management. J. Environ. Manag. 2017, 204, 230-245. [CrossRef]

53. Domínguez-Tejo, E.; Metternicht, G.; Johnston, E.L.; Hedge, L. Exploring the social dimension of sandy beaches through predictive modelling. J. Environ. Manag. 2018, 214, 379-407. [CrossRef] [PubMed]

54. Dvarskas, A. Dynamically linking economic models to ecological condition for coastal zone management: Application to sustainable tourism planning. J. Environ. Manag. 2017, 188, 163-172. [CrossRef]

55. Buckley, R. Tourism eco-labels. Ann. Tour. Res. 2002, 29, 188-208. [CrossRef]

56. Boevers, J. Assessing the utility of beach eco-labels for use by local management. Coast. Manag. 2008, 36, 524-531. [CrossRef]

57. Vallega, A. Fundamentals of Integrated Coastal Management; Kluwer Publishers: Dordrecht, The Netherlands, 1999.

58. François, C. Poder y Trampas de la Inteligencia Social; Documentos del GESI: Buenos Aires, Argentina, 1997.

59. WTO. Voluntary Initiatives for Sustainable Tourism; World Tourism Organization: Madrid, Spain, 2002; ISBN 978-92-844-0509-1.

60. Silva, C.P. Beach Carrying Capacity Assessment: How important is it? J. Coast. Res. 2002, SI36, 190-197. [CrossRef]

61. Vaz, B. Contributos Para a Avaliação e Gestão de Praias: A Importância da Percepção dos Seus Utilizadores. Tesis de Mestre en Ecologia Humana y Problemas Sociales Contemporáneos; Universidade Nova de Lisboa: Lisboa, Portugal, 2008.

62. JCPV. Fundamentación y Reglamento del Sistema de Certificación PAM; Junta Coordinadora Playa de Varadero: Varadero, Cuba, 2008.

63. Bendell, J.; Font, X. Which tourism rules? Green Standards and GATS. Ann. Tour. Res. 2004, 31, 139-156. [CrossRef]

64. Dadón, J. Playas y Balnearios de Calidad: Gestión Turística y Ambiental. Directrices y Guía de Autoevaluación; Secretaria de Ambiente y Desarrollo Sustentable: Buenos Aires, Argentina, 2005.

65. Brewster, B.C. Lifesaving and beach safety. In Encyclopedia of Coastal Science, 2nd ed.; Schwartz, M., Ed.; Springer: Dordrecht, The Netherlands, 2005; pp. 589-592.

66. Dodds, R.; Holmes, M.R. Beach tourists; what factors satisfy them and drive them to return. Ocean Coast. Manag. 2019, 168, 158-166. [CrossRef] 